21. Matheny, S.A., et al. 2004. Ras regulates assembly of mitogenic signalling complexes through the effector protein IMP. Nature. 427:256-260.

22. Wang, X., and Studzinski, G.P. 2001. Phosphorylation of raf- 1 by kinase suppressor of ras is inhibited by "MEK-specific" inhibitors PD 098059 and U0126 in differentiating HL60 cells. Exp. Cell Res. 268:294-300.

23. Xing, H.R., and Kolesnick, R. 2001. Kinase suppressor of Ras signals through Thr269 of c-Raf-1. J. Biol. Chem. 276:9733-9741.

24. Wang, X., and Studzinski, G.P. 2004. Kinase suppressor of RAS (KSR) amplifies the differentiation signal provided by low concentrations 1,25-dihydroxyvitamin D3. J. Cell. Physiol. 198:333-342.

25. Xing, H.R., Campodonico, L., and Kolesnick, R. 2004. The kinase activity of kinase suppressor of Ras1 (KSR1) is independent of bound MEK. J. Biol. Chem. 279:26210-26214.

26. Xing, H.R., Lozano, J., and Kolesnick, R. 2000 Epidermal growth factor treatment enhances the kinase activity of kinase suppressor of Ras. J. Biol. Chem. 275:17276-17280.

27. Galve-Roperh, I., et al. 2000. Anti-tumoral action of cannabinoids: involvement of sustained ceramide accumulation and extracellular signal-regulated kinase activation. Nat. Med. 6:313-319.

28. Grassme, H., Schwarz, H., and Gulbins, E. 2001. Molecular mechanisms of ceramide-mediated CD95 clustering. Biochem. Biophys. Res. Commun. 284:1016-1030.

29. Abdel Shakor, A.B., Kwiatkowska, K., and Sobota, A. 2004. Cell surface ceramide generation precedes and controls Fcgamma RII clustering and phosphorylation in rafts. J. Biol. Chem. 279:36778-36787.

30. van Blitterswijk, W.J. 1998. Hypothesis: ceramide conditionally activates atypical protein kinases C, Raf- 1 and KSR through binding to their cysteinerich domains. Biochem. J. 331:679-680.

31. Yao, B., et al. 1995. Phosphorylation of Raf by ceramide-activated protein kinase. Nature. 378:307-310.

32. Mathias, S., Dressler, K.A., and Kolesnick, R.N 1991. Characterization of a ceramide-activated protein kinase: stimulation by tumor necrosis factor alpha. Proc. Natl. Acad. Sci. U. S. A. 88:10009-10013.

33. Joseph, C.K., Byun, H.S., Bittman, R., and Kolesnick, R.N. 1993. Substrate recognition by ceramide-activated protein kinase. Evidence that kinase activity is proline-directed. J. Biol. Chem. 268:20002-20006.

34. Liu, J., Mathias, S., Yang, Z., and Kolesnick, R.N. 1994. Renaturation and tumor necrosis factoralpha stimulation of a $97-\mathrm{kDa}$ ceramide-activated protein kinase. J. Biol. Chem. 269:3047-3052.

35. Basu, S., Bayoumy, S., Zhang, Y., Lozano, J., and Kolesnick, R. 1998. BAD enables ceramide to signal apoptosis via Ras and Raf-1. J. Biol. Chem. 273:30419-30426.

36. Xing, H.R., et al. 2003. Pharmacologic inactivation of kinase suppressor of ras- 1 abrogates Ras-mediated pancreatic cancer. Nat. Med. 9:1266-1268.

37. Joneson, T., et al. 1998. Kinase suppressor of Ras inhibits the activation of extracellular ligandregulated (ERK) mitogen-activated protein (MAP) kinase by growth factors, activated Ras, and Ras effectors. J. Biol. Chem. 273:7743-7748.

38. Cacace, A.M., et al. 1999. Identification of constitutive and ras-inducible phosphorylation sites of KSR: implications for 14-3-3 binding, mitogenactivated protein kinase binding, and KSR overexpression. Mol. Cell. Biol. 19:229-240.

39. Kortum, R.L., and Lewis, R.E. 2004. The molecular scaffold KSR1 regulates the proliferative and oncogenic potential of cells. Mol. Cell. Biol. 24:4407-4416.

40. Lozano, J., et al. 2003. Deficiency of kinase suppressor of Ras1 prevents oncogenic ras signaling in mice. Cancer Res. 63:4232-4238.

41. Michaud, N.R. et al. 1997. KSR stimulates Raf-1 activity in a kinase-independent manner. Proc. Natl. Acad. Sci. U. S. A. 94:12792-12796.
42. Volle, D.J., et al. 1999. Phosphorylation of the kinase suppressor of ras by associated kinases. Biochemistry. 38:5130-5137.

43. Zhou, M., Horita, D.A., Waugh, D.S., Byrd, R.A., and Morrison, D.K. 2002. Solution structure and functional analysis of the cysteine-rich $\mathrm{C} 1$ domain of kinase suppressor of Ras (KSR). J. Mol. Biol. 315:435-446.

44. Muller, J., Cacace, A.M., Lyons, W.E., McGill, C.B., and Morrison, D.K. 2000. Identification of B-KSR1, a novel brain-specific isoform of KSR1 that functions in neuronal signaling. Mol. Cell. Biol. 20:5529-5539.

45. Sugimoto, T., Stewart, S., Han, M., and Guan, K.L. 1998. The kinase suppressor of Ras (KSR) modulates growth factor and Ras signaling by uncoupling Elk-1 phosphorylation from MAP kinase activation. EMBO J. 17:1717-1727.

46. Johnson, L.N., Lowe, E.D., Noble, M.E., and Owen, D.J. 1998. The Eleventh Datta Lecture. The structural basis for substrate recognition and control by protein kinases. FEBS Lett. 430:1-11.

47. Spitaler, M., Villunger, A., Grunicke, H., and Uberall, F. 2000. Unique structural and functional properties of the ATP-binding domain of atypical protein kinase C-iota. J. Biol. Chem. 275:33289-33296.

48. Tsakraklides, V., and Solomon, M.J. 2002. Comparison of Cak1p-like cyclin-dependent kinase-activating kinases. J. Biol. Chem. 277:33482-33489.

49. Kaldis, P., et al. 1998. Localization and regulation of the cdk-activating kinase (Cak1p) from budding yeast. J. Cell. Sci. 111:3585-3596.

50. Xu, B.E., et al. 2002. Regulation of WNK1 by an autoinhibitory domain and autophosphorylation. J. Biol. Chem. 277:48456-48462.

51. Xu, B., et al. 2000. WNK1, a novel mammalian serine/ threonine protein kinase lacking the catalytic lysine in subdomain II. J. Biol. Chem. 275:16795-16801.

52. Verissimo, F., and Jordan, P. 2001. WNK kinases, a novel protein kinase subfamily in multi-cellular organisms. Oncogene. 20:5562-5569.

\title{
p16 and ARF: activation of teenage proteins in old age
}

\author{
Ande Satyanarayana and K. Lenhard Rudolph
}

Department of Gastroenterology, Hepatology, and Endocrinology, Hannover Medical School, Hannover, Germany.

\begin{abstract}
Cellular senescence induced by different stresses and telomere shortening appears to play an important role in the aging process. The products of the INK4a/ARF locus - $\mathrm{p}^{16^{\mathrm{INK}} \mathrm{Ia}^{\mathrm{a}}}$ and ARF - arrest cell proliferation at the senescence stage by exerting their effects on retinoblastoma protein-and p53-mediated responsive pathways. A study in this issue of the JCI provides experimental evidence of a specific upregulation of these cell cycle inhibitors in a variety of organs during mammalian aging (see the related article beginning on page 1299).
\end{abstract}

Nonstandard abbreviations used: $C D K$, cyclin-dependent kinase; $\mathrm{CDKI}$, CDK inhibitor; $\mathrm{CR}$, caloric restriction; $\mathrm{GH}$, growth hormone; GHR, GH receptor; MDM2, mouse double minute 2 ; $\mathrm{pRB}$, retinoblastoma protein; SA- $\beta$-gal, senescence-associated $\beta$-galactosidase.

Conflict of interest: The authors have declared that no conflict of interest exists.

Citation for this article: J. Clin. Invest. 114:1237-1240 (2004). doi:10.1172/JCI200423437.
According to a current hypothesis on aging, senescent cells accumulate in the organism, and this results in failure of organ homeostasis and function (1). Cellular senescence - characterized by the permanent arrest of cell proliferation - is detrimental to the regenerative capacity of organs during aging. However, the senes- cence checkpoint is also considered to be a major mechanism for suppressing tumors, protecting the organism from cancer during early life (2). A number of stimuli have been identified as inducing senescence, and these include telomere shortening (3), DNA damage (4), oxidative stress (5), sustained mitogen stimulation (6), and other cellular stresses. Senescence induced by telomere shortening has been called "replicative senescence" and is a result of DNA damage-like signals generated by dysfunctional telomeres $(3,4)$. In addition to telomere attrition, several other mechanisms can abruptly induce senescence independent of telomere length, termed "premature senescence," including: over- 


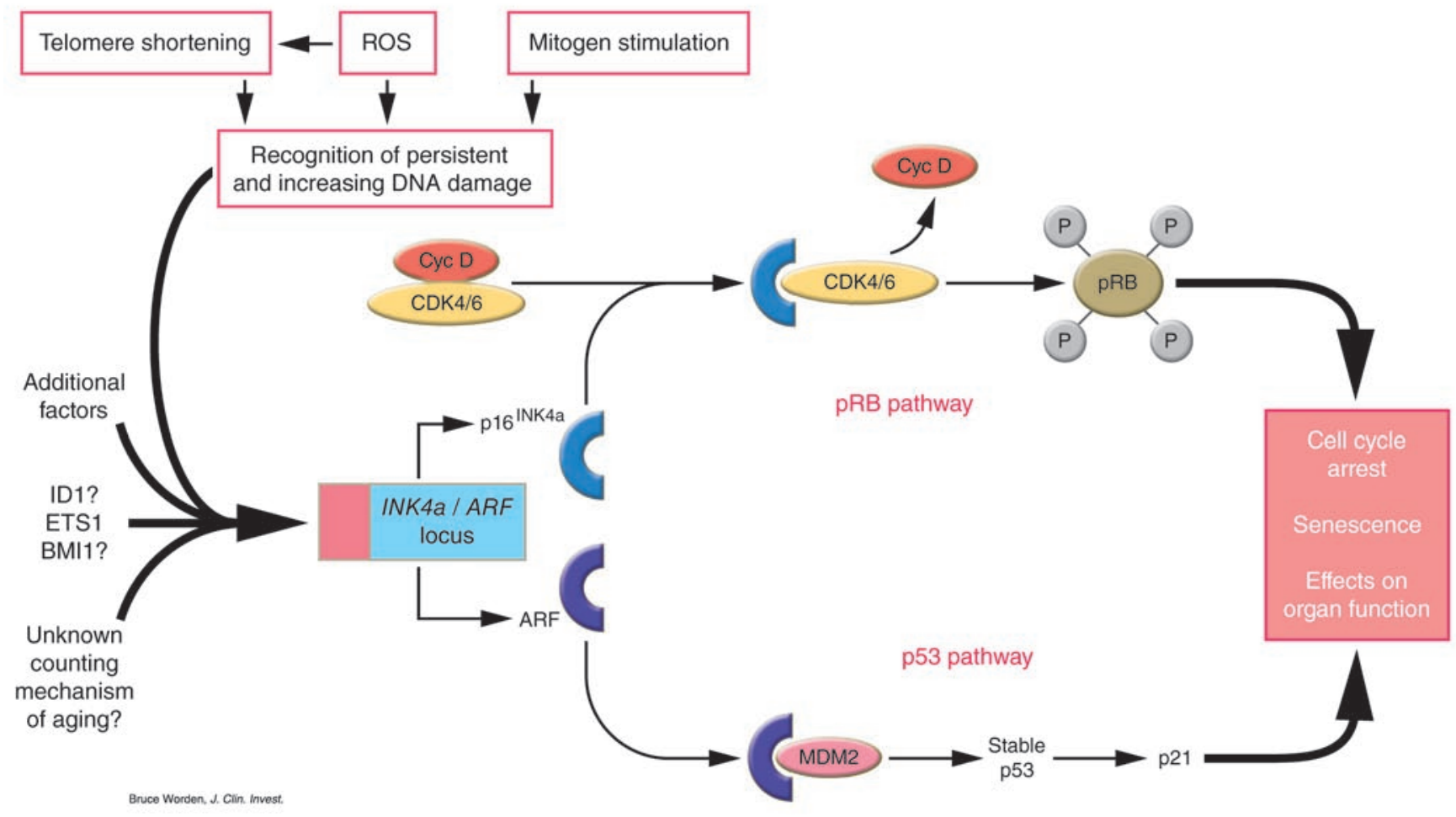

Figure 1

Illustration showing possible mechanisms of $\mathrm{p} 16^{\mathrm{INK} 4 \mathrm{a}}$ and ARF induction and the role of these proteins in aging. The accumulation of persistent and increasing DNA damage in senescent cells in response to telomere shortening, DNA damage, inappropriate activation of signaling pathways, and production of ROS during aging results in transcriptional activation of the INK4a/ARF locus. Mitogen stimulation may amplify the signals of

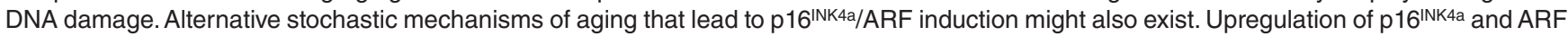
activates pRB and p53 pathways, which in turn lead to cell cycle arrest and regenerative defects. In addition, p16 INK4a/ARF upregulation might influence cellular functions in mitotically inactive organs during aging. Cyc D, cyclin D; BMI1, B lymphoma Mo-MLV insertion region; ID1, inhibitor of DNA binding 1; ETS1, v-ets erythroblastosis virus E26 oncogene homolog 1.

activation of mitogenic pathways, such as Ras, Raf, or MEK, or overexpression of E2F or v-ets erythroblastosis virus E26 oncogene (Ets) transcription factors (5-9). The mechanisms leading to induction of premature senescence are less well understood compared with those leading to replicative senescence. However, the phenotypic characteristics and the molecular signals of premature senescence and replicative senescence appear to be very similar.

Under normal circumstances, cell cycle initiation and progression is cooperatively regulated by several classes of cyclin-dependent kinases (CDKs), whose activities are in turn regulated by CDK inhibitors (CDKIs). To allow cell cycle progression, retinoblastoma protein $(\mathrm{pRB})$ is phosphorylated by a holoenzyme complex containing cyclin D and a cyclin-dependent kinase (CDK4 or CDK6) (10). The INK4 family of CDKIs comprises a number of small ("teenage") proteins - p16 ${ }^{\mathrm{INK} 4 \mathrm{a}}$, p14 ${ }^{\mathrm{ARF}}$ (murine p19 ARF$^{\mathrm{A}}$ ), p15 INK4b $^{\mathrm{I}}$, and p18 $8^{\text {INK } 4 c}-$ all of which have a role in cell cycle regulation (10). In this commentary, p14 ${ }^{\mathrm{ARF}}$ (murine p19 ${ }^{\mathrm{ARF}}$ ) will be referred to as ARF. Residing on chromosome 9p21 in humans and chromosome 4 (42.7) in mice, the INK4a/ARF locus encodes 2 different proteins, $\mathrm{p} 16^{\mathrm{INK} 4 \mathrm{a}}$ and ARF, via an alternative splicing mechanism. Lack of either protein predisposes the organism to the development of malignancy, though neither protein is required for normal growth and development. ARF and p16 ${ }^{\mathrm{INK} 4 \mathrm{a}}$ have long been recognized as mediators of senescence (6-8) (Figure 1). p16 $6^{\mathrm{INK} 4 \mathrm{a}}$ binds and induces an allosteric conformational change in CDK4/CDK6 that inhibits the binding of ATP and substantially reduces the formation of the CDK4/6-cyclin D interface, which leads to the disruption of the interaction with D-type cyclins. This antagonizes cyclin binding and activation of CDK, thereby maintaining $\mathrm{pRB}$ in its hypophosphorylated and growth-suppressive state and induces $G_{1}$ cell cycle arrest (10). In contrast to $\mathrm{p} 16^{\mathrm{INK} 4 \mathrm{a}}, \mathrm{ARF}$ has a major role in the pathway involving p53, a transcription factor that regulates several genes involved in cell cycle checkpoints, stress responses, DNA damage and repair, and apoptosis (Figure 1) (2). ARF binds the mouse double minute 2 (MDM2) protein and inhibits MDM2-mediated degradation of $\mathrm{p} 53$, which thus results in stabilization of p53. One of the important targets of p53 is the CDKI p21 Cip1/Waf1, which inhibits the activity of several cyclin-CDK complexes, thus arresting cells in both $\mathrm{G}_{1}$ and $\mathrm{G}_{2} / \mathrm{M}$ stages of the cell cycle (10).

Understanding the role of $\mathrm{p} 16^{\mathrm{INK} 4 \mathrm{a}}$ and ARF during senescence has been complicated due to apparent differences between the mechanisms of senescence signalling induced by telomere dysfunction in mice and humans. In humans, telomere dysfunction induces senescence by activation 
of p53 and p16 ${ }^{\text {INK4a }}$, whereas in mice only p53 is activated in response to telomere dysfunction (11). In addition, there might be differences in regulation of $\mathrm{p} 16^{\mathrm{INK} 4 \mathrm{a}}$ and ARF during replicative senescence and premature senescence. Whereas both genes are upregulated during premature senescence, only 16 but not ARF is upregulated during replicative senescence. During replicative senescence, upregulation of $\mathrm{p} 16^{\mathrm{INK} 4 \mathrm{a}}$ occurs shortly after the activation of $\mathrm{p} 21$, possibly to ensure maintenance of the senescence phenotype (12). Functional screens have shown that downregulation of ARF can rescue premature senescence (13). Understanding the regulation of $\mathrm{p} 16^{\mathrm{INK} 4 \mathrm{a}}$ and ARF in the different senescence pathways, the interaction between the pathways, and the functional role of these proteins during regeneration of organs and organismal aging are major questions for future research.

\section{p16 INK4a and ARF: molecular markers of aging?}

In this issue of the JCI, Krishnamurthy et al. (14) attempted to identify molecular markers of aging in mice and rats by exploring the expression levels of several known cell cycle inhibitors. They show that the expression levels of both $\mathrm{p} 16^{\text {INK4a }}$ and ARF mRNA markedly increase with aging in most murine tissues, whereas there is no significant change in the expression levels of other related cell cycle inhibitors such as $\mathrm{p} 15^{\mathrm{INK} 4 \mathrm{~b}}$, $\mathrm{p} 18^{\mathrm{INK} 4 \mathrm{c}}, \mathrm{p} 21^{\mathrm{CIP}}$, and $\mathrm{p} 27^{\mathrm{KIP}}$ with aging. The authors substantiated their findings by demonstrating increased $\mathrm{p} 16^{\mathrm{INK} 4 \mathrm{a}}$ and ARF protein expression in some organ compartments. They found that in several organ compartments, the increase in the expression of $\mathrm{p} 16^{\mathrm{INK} 4 \mathrm{a}}$ and ARF was accompanied by an increased number of cells positive for senescence-associated $\beta$-galactosidase (SA$\beta$-gal) - a biomarker of cellular senescence. While SA- $\beta$-gal has been used as a biomarker of senescence in vitro and in vivo, its lack of specificity has led to debate over the value of this method. However, although SA- $\beta$-gal is activated in response to several cellular stresses (15), it is still considered to be one of the best markers of senescence available today. It remains to be tested whether the accumulation of DNA-damage foci is a more specific marker for senescence. DNA damage foci accumulate in senescent cells with shortened telomeres; however, it is not yet clear whether they are present during premature senescence (16).

Krishnamurthy et al. show that the age-associated increase in expression of p $16^{\text {INK4a }}$ and ARF is attenuated in several tissues in response to caloric restriction (CR). CR is known to extend life span in a variety of species, including rats, mice, fish, flies, worms, and yeast. In addition, reduction of aging-associated pathology is evident in primates fed a calorie-restricted diet (17). The authors extended their studies further by exploring the role of p $16^{\mathrm{INK} 4 \mathrm{a}}$ and ARF in Igf1-null mice. There is experimental evidence that the lack of growth hormone-IGF (GH-IGF) signaling increases the lifespan in GH receptor (GHR) knockout (Ghr-/-) mice by approximately 25\% (18). Krishnamurthy et al. did not see an impairment of p16 $6^{\mathrm{INK} 4 \mathrm{a}}$ or ARF expression in aging $\mathrm{Ghr}^{-1}$ mice, which suggests that GHR deficiency and CR extend the life span of organisms through distinct molecular mechanisms and that $\mathrm{p} 16^{\mathrm{INK} 4 a}$ and ARF expression levels do not always correlate with lifespan.

\section{Tangled regulation of $\mathrm{p} 16^{\text {INK4 }}$ and ARF during aging}

At the level of transcription, the expression of $p 16^{I N K 4 a}$ is modulated by 3 principal regulators: ETS1, inhibitor of DNA binding 1 (ID1), and B lymphoma Mo-MLV insertion region (BMI1) $(19,20)$. The latter is also known to regulate $A R F$ expression. Krishnamurthy et al. (14) found a strong correlation between the expression levels of $p 16^{I N K 4 a}$ and Ets-1, p16 INK4 and ARF, but not between $A R F$ and any of these 3 transcriptional regulators. These findings led to the speculation that an unknown coregulator(s) affects the expression of both $p 16^{\text {INK4a }}$ and $A R F$ with aging and that this coregulator(s) must be independent of Ets-1. In addition, the authors present what is believed to be the first in vivo evidence for a coordinated expression of $\mathrm{p} 18^{\mathrm{INK} 4 \mathrm{c}}$ and $\mathrm{p} 19^{\mathrm{INK} 4 \mathrm{~d}}$, possibly regulated by common or related transcriptional elements. With these studies as a basis, exploration of transcriptional control of the INK $4 a$ locus appears to be an interesting area of aging research (Figure 1).

\section{What is the functional role and the mechanism of induction of p16 INK4a and ARF during aging?}

The study by Krishnamurthy et al. (14) appears to be of general interest, since the development of reliable biomarkers of aging will certainly be immensely useful in various areas of medicine. It is tempting to speculate that $\mathrm{p} 16^{\mathrm{INK} 4 \mathrm{a}}$ and/or ARF are not only good candidate biomarkers of aging, but that they may in fact have a function- al role in the aging process. p16 $6^{\mathrm{INK} 4 \mathrm{a}}$ and ARF have both been linked to the induction of cell cycle arrest in response to DNA damage $(21,22)$. This finding seems of particular interest, since there are several connections among the different senescence stimuli that point to DNA damage as a major factor inducing senescence: (a) telomere shortening induces senescence by activation of the DNA-damage response (16); (b) ROS increase the rate of telomere shortening and induces multiple forms of DNA damage $(23,24)$; and (c) mitogen stimulation cooperates with telomere shortening to induce a DNAdamage response (25). It has recently been shown that DNA damage accumulates in senescent cells and aging murine tissues (26). Thus the DNA-damage hypothesis of aging could give a plausible explanation for the upregulation of $\mathrm{p} 16^{\mathrm{INK} 4 \mathrm{a}}$ and ARF during aging. Alternatively p $16^{\mathrm{INK} 4 \mathrm{a}}$ and ARF upregulation during aging might be regulated by an as-yet-unknown counting mechanism that differs from accumulation of DNA damage or telomere shortening (Figure 1). Understanding the signaling pathways involved in $\mathrm{p} 16^{\mathrm{INK} 4 a}$ and ARF upregulation in organs and tissues could eventually point to new therapeutic targets to improve regenerative capacity during aging. Importantly, the experimental evidence for a functional role of $\mathrm{p} 16^{\mathrm{INK} 4 \mathrm{a}}$ and ARF in the aging process has yet to be established. Studies focused on the tumor suppressor p53 have revealed diverse results regarding the role of this key component of the senescence pathway during aging. In mouse models, the deletion of p53 has rescued the adverse effect of telomere dysfunction on organ homeostasis (27), whereas transgenic expression of a mutant $\mathrm{p} 53$ with increased protein stability induced premature aging (28), which indicates that p53 is indeed a mediator of aging phenotypes. However, inserting an extra copy of wild-type p53 in the mouse genome resulted in increased p53 activity in response to DNA damage and improved tumor suppression but did not enhance aging phenotypes (29). In this model, the extremely long telomeres in laboratory inbred mouse strains compared with house mice or humans might explain the lack of premature aging. To date there are no reports of improved organ regeneration in aging knockout mice lacking $p 16^{\text {Ink } 4 a}$ or $A R F$ or both genes. In addition, it is not known whether transgenic mice with increased expression levels of 1 of 
these proteins would develop premature aging phenotypes. However, there is indirect evidence from studies in proliferation associated SNF-2-like gene-knockout (PASGknockout) mice, which have a defect in DNA-methylation. These mice show a severe premature aging phenotype accompanied by decreased expression of Bmi1 (a negative regulator of both $\mathrm{p} 16^{\mathrm{INK} 4 \mathrm{a}}$ and ARF) and increased levels of p16 ${ }^{\text {INK4a }}(30)$. It is interesting that Krishnamurthy et al. (14) observed an upregulation of $\mathrm{p} 16^{\mathrm{INK} 4 a}$ and ARF in a wide spectrum of different organs and tissues in aging mice. Many of these tissues are mitotically inactive; thus, it appears to be important to analyze the impact of p16 $16^{\mathrm{INK} 4 \mathrm{a}}$ and ARF on cellular functions other than cell proliferation to evaluate their role in aging (Figure 1). In addition, these findings suggest that there might be a secreted factor leading to upregulation of $\mathrm{p} 16^{\mathrm{INK} 4 \mathrm{a}}$ and ARF in a variety of organs during aging.

The constant increase in maximum lifespan of human beings over recent centuries is certainly one of the biggest achievements of humankind. The identification and functional analysis of aging-associated molecular changes appears to be a promising area of research and should help us continue to make gains in this area.

Address correspondence to: Karl Lenhard Rudolph, Department of Gastroenterology, Hepatology, and Endocrinology, Medical School Hannover, Carl-Neuberg-Strasse 1, 30625 Hannover, Germany. Phone: 0049-511-5326999; Fax: 0049-511-532-6998; E-mail: Rudolph.Lenhard@Mh-Hannover.de.
1. Kim, S., Kaminker, P., and Campisi, J. 2002. Telomeres, aging and cancer: in search of a happy ending. Oncogene. 21:503-511.

2. Sharpless, N.E., and DePinho, R.A. 2002. p53: good cop/bad cop. Cell. 110:9-12.

3. Campisi, J. 1997. The biology of replicative senescence. Eur. J. Cancer. 33:703-709.

4. Reaper, P.M., di Fagagna, F., and Jackson, S.P. 2004. Activation of the DNA damage response by telomere attrition: a passage to cellular senescence. Cell Cycle. 3:543-546.

5. Chen, Q.M., et al. 1998. Molecular analysis of H2O2induced senescent-like growth arrest in normal human fibroblasts: p53 and Rb control G1 arrest but not cell replication. Biochem. J. 332:43-50.

6. Lin, A.W., et al. 1998. Premature senescence involving $\mathrm{p} 53$ and $\mathrm{p} 16$ is activated in response to constitutive MEK/MAPK mitogenic signaling. Genes Dev. 12:3008-3019.

7. Huschtscha, L.I., and Reddel, R.R. 1999 $\mathrm{p} 16$ (INK4a) and the control of cellular proliferative life span. Carcinogenesis. 20:921-926.

8. Ferbeyre, G., et al. 2002. Oncogenic ras and p53 cooperate to induce cellular senescence. Mol. Cell. Biol. 22:3497-3508.

9. Rowland, B.D., et al. 2002. E2F transcriptional repressor complexes are critical downstream targets of $\mathrm{p} 19(\mathrm{ARF}) / \mathrm{p} 53$-induced proliferative arrest. Cancer Cell. 2:55-65.

10. Sherr, C.J., and Roberts, J.M. 1999. CDK inhibitors: positive and negative regulators of G1-phase progression. Genes Dev. 13:1501-1512.

11. Smogorzewska, A., and de Lange, T. 2002. Different telomere damage signaling pathways in human and mouse cells. EMBO J. 21:4338-4348.

12. Stein, G.H., Drullinger, L.F., Soulard, A., and Dulic, V. 1999. Differential roles for cyclin-dependent kinase inhibitors p21 and p16 in the mechanisms of senescence and differentiation in human fibroblasts. Mol. Cell. Biol. 19:2109-2117.

13. Shvarts, A., et al. 2002. A senescence rescue screen identifies BCL6 as an inhibitor of anti-proliferative p19(ARF)-p53 signaling. Genes Dev. 16:681-686.

14. Krishnamurthy, J., et al. 2004. Ink4a/Arf expression is a biomarker of aging. J. Clin. Invest. 114:1299-1307. doi:10.1172/JCI200422475.

15. Severino, J., Allen, R.G., Balin, S., Balin, A., and Cristofalo, V.J. 2000. Is beta-galactosidase staining a marker of senescence in vitro and in vivo? Exp. Cell Res. 225:162-171.

16. d'Adda di Fagagna, F., et al. 2003. A DNA damage checkpoint response in telomere-initiated senes- cence. Nature. 426:194-198.

17. Lane, M.A., et al. 2001 Caloric restriction in primates. Ann. N. Y. Acad. Sci. 928:287-295.

18. Bartke, A., et al. 2003. Insulin-like growth factor 1 (IGF-1) and aging: controversies and new insights. Biogerontology. 4:1-8.

19. Ohtani, N., et al. 2001. Opposing effects of Ets and Id proteins on p16INK4a expression during cellular senescence. Nature. 409:1067-1070.

20. Jacobs, J.J., Kieboom, K., Marino, S., DePinho, R.A., and van Lohuizen, M. 1999. The oncogene and Polycomb-group gene bmi-1 regulates cell proliferation and senescence through the ink 4 a locus. Nature. 397:164-168.

21. Shapiro, G.I., Edwards, C.D., Ewen, M.E., and Rollins, B.J. 1998. p16INK4A participates in a G1 arrest checkpoint in response to DNA damage. Mol. Cell. Biol. 18:378-387.

22. Honda, R., and Yasuda, H. 1999. Association of p19(ARF) with Mdm2 inhibits ubiquitin ligase activity of $\mathrm{Mdm} 2$ for tumor suppressor p53. ЕМВО J. 18:22-27.

23. Ramirez, R.D., et al. 2001. Putative telomereindependent mechanisms of replicative aging reflect inadequate growth conditions. Genes Dev. 15:398-403.

24. Liu, L., Trimarchi, J.R., Smith, P.J., and Keefe, D.L. 2002. Mitochondrial dysfunction leads to telomere attrition and genomic instability. Aging Cell. 1:40-46.

25. Satyanarayana, A., et al. 2004. Mitogen stimulation cooperates with telomere shortening to activate DNA damage responses and senescence signaling. Mol. Cell. Biol. 24:5459-5474.

26. Sedelnikova, O.A., et al. 2004. Senescing human cells and ageing mice accumulate DNA lesions with unrepairable double-strand breaks. Nat. Cell. Biol. 6:168-170.

27. Chin, L., et al. 1999. p53 deficiency rescues the adverse effects of telomere loss and cooperates with telomere dysfunction to accelerate carcinogenesis. Cell. 97:527-538.

28. Tyner, S.D., et al. 2002. p53 mutant mice that display early ageing-associated phenotypes. Nature. 415:45-53.

29. Garcia-Cao, I., et al. 2002. "Super p53” mice exhibit enhanced DNA damage response, are tumor resistant and age normally. EMBOJ. 21:6225-6235.

30. Sun, L.Q., et al. 2004. Growth retardation and premature aging phenotypes in mice with disruption of the SNF2-like gene, PASG. Genes Dev. 18:1035-1046. 